\title{
Aspekty medyczno-prawne dotyczące żywienia w kontekście bezpieczeństwa ekologicznego żywności
}

\author{
Julia Świerżewska, Salomea Kaszczewska, Wojtek Młodziejewski \\ Collegium ,Masovia”, Warszawa-Lviv-Sydnej \\ Отримано 12.05.2021, принято 19.05.2021 \\ https://doi.org/10.32347/tit2141.0207
}

They know better all the features and risks of their business, and therefore they must be responsible for their safety. Implementation of the main elements of the new food safety control system in Ukraine takes place through the implementation of a permanent procedure based on the HACCP principles [1-3]. Now, entrepreneurs must identify potential hazards and risks of the production process and capacities, as well as take all necessary measures to minimize them. Together with greater responsibility the entrepreneurs receive more freedom. For example, the state cannot require the factory to have light walls above $1.8 \mathrm{~m}$. The quality is a subjective and personal concept, and safety requirements must prevent the harmful effects of products on the health of the consumer. At the same time, Ukrainians need to know what they are consuming. Therefore, lawmakers are currently working on a draft law on providing information to consumers about food. The new system to which Ukraine passes allows a clear distinction to be drawn between liabilities for causing harm due to the consumption of a dangerous product. According to the concept of the food chain «from the lawn to the table», the quality of the product must be baked at each stage of the commodity circulation, and each businessman is responsible for the safety of the food within its activities: the manufacturer - within the limits of production, the carrier - within the scope of transportation, the store - within storage and sale. Consequently, at each point of the food chain, the entrepreneur knows where the raw material or product came from and where it comes next. If the customer receives a health hazard product, this system helps to identify: who is responsible for causing harm. In this chain, there should be feed for productive animals. The draft law «On Safety and Hygiene of Forms» has already been developed and registered. If the feed contains harmful substances, they will continue to enter our body through products made from animal meat. Therefore, the feed safety is extremely important for our health. The new system also requires fundamentally new approaches to state control of food safety. The state inspector should not only check the unit of the goods as in Soviet times. The organization of the inspector work is primarily to assess the safety of the conditions of production of the entire product batch at the enterprise. He looks at whether all possible risks are minimized. Only in this way can the safety of all products be guaranteed. For example, breeding pigs, carcass separation and minced meat products contain more potential hazards than tea, coffee and sweets. The frequency of inspections will also depend on the reputation and previous violations of the law by the enterprise. The more such violations, the more often the state inspector will come. At the same time, the violation of the food safety in accordance with the new system provides for high fines, and in exceptional cases, even the closing of power is possible. Thus, the Law on Control stipulates that, in the event of a retail sale of food and life -threatening products, the State Committee for Proprietary Consumer Protection immediately discloses this fact on its website information that allows consumers to identify the relevant product. Thus, entrepreneurs who are grossly violating the law will be able to be advertised. Although some elements of the new system of state food control cause certain concerns among entrepreneurs, there is hardly any alternative to ensuring uniform rules of the game on the market and increasing the competitiveness of domestic enterprises within the framework of a globalized economy 
The use of emulsions in the manufacture of beverages is associated with the possibility of reducing the length of the production process while reducing power consumption compared to traditional production methods. This difference is particularly useful in food industry, because of the emulsions are the necessary ingredients that provide flavor, color and aroma of food that greatly simplifies their production technology. Having information about the size of emulsion particles can be controlled their stability and quality. It is known that the emulsion particle diameter depends on the technology of the manufacturing process, the formulation of the emulsion. The key point of the efficiency of the food industry is the introduction of resource-saving and competitive technologies based on the use of high quality components of food and beverages. The paper discusses the main factors controlling flocculation, creaming, coalescence and Ostwald ripening, distinguishing between the differing effects of adsorbing and no adsorbing hydrocolloids. The principle of leverage ratio of water and oil phase of emulsions with different stabilizers is the same. In the obtained parameters also affects the nature of emulsions stabilizer. During storage of beverages prepared from emulsions studied, there was no formation of oil ring or - creaming $\|$ bottled, indicating the stability of emulsion systems. The use of aromatic emulsions in the manufacture of soft drinks has several benefits, includ- ing: reduced duration blending, as there is no need to pick up the dye. The use of aromatic emulsions drinks solves the problem of stabilizing the aroma and taste, as in this case acts as an emulsifier adsorbent aroma of providing fine and mild flavor. The process of storing drinks not observed the emergence of oil rings on the surface of the drink, there was no change in color, taste and aroma of the drink. Color Stability ensured using synthetic dyes stable in comparison with natural dyes, direct sunlight during shelf life. Creating a stable emulsion system is a pressing issue in the food industry, so these studies are useful and important for the development of new beverages.

\section{REFERENCES}

1. Lugovska, O.A. \& Sydor V.M. (2016) Use emulsions in production restaurants and food industry. Food and environment safety: journal of faculty of food engineering, $\mathrm{XV}, 312-322$.

2. Lugovska, O.A. \& Sydor V.M. (2015) Influence of hydrocolloids in oil-in-water emulsions during storage of food. Food and environment safety, XIV, 84-88.

3. Lugovska, O.A. \& Sydor V.M. (2015) Aromatic emulsion beverage catering and industrial production. Journal of FOOD and PACKAGING Science, Technique and Technologies, 7, 19-23.

4. Wysoczańska J. (2014) Praca magisterska. Uniwersytet Warszawski Medyczny. 